ISSN: 2146-3042

DOI: $10.25095 /$ mufad.465904

\title{
Şirketlerin Bağımsız Denetim Raporlarının Analizi: Borsa İstanbul'da Bir Araştırma
}

\author{
Bilge SEKİZSU * \\ Fatih Coşkun ERTAŞ ${ }^{* *}$
}

\section{ÖZET}

Bu çalışmada bağımsız denetimde uygulanan Sermaye Piyasası Kurulu (SPK) tarafindan yayınlanan Denetim Standartları'ndan, Kamu Gözetimi, Muhasebe ve Denetim Standartları Kurumu (KGK) tarafindan yayınlanan Türkiye Denetim Standartlarl'na (TDS) geçiş yılı olan 2013 ve 2014 yllında Borsa İstanbul'da işlem gören şirketlerin denetim raporları ve bu raporlarda yer alan denetim görüşleri incelenmiştir. Denetim raporlarının SPK Denetim Standartlarl ve Türkiye Denetim Standartları tebliğlerine uygunluk dereceleri ile denetim görüşleri ve uygulanan standart setlerinin, denetim şirketleri ile aralarında bir ilişki olup olmadığ araştırılmıştır. 2013 yılında denetim görüşleri, denetim şirketlerine göre farklılaşmaktadır, denetimde kullanılan standart setine göre farklılaşmamaktadır. Buna karşılık standart seti denetim şirketlerine göre farklılaşmaktadır. 2014 yllında ise denetim görüşleri, denetim şirketlerine ve standart setine göre, standart seti de denetim şirketlerine göre farklılaşmaktadır.

Anahtar Kelimeler: Bağımsız Denetim, Denetim Raporu, Denetim Şirketi, Türkiye Denetim Standartları, Kamu Gözetimi, Muhasebe ve Denetim Standartları Kurumu, Borsa İstanbul.

JEL Sinıflandırması: M41, M42, M49.

Analysis Of Independent Audit Reports By Companies: A Research In The Stock Exchange İstanbul ABSTRACT

It have been passed from Capital Markets Board (CMB) Auditing Standards applied in independent audit to Turkey Auditing Standards published by the Public Oversight, Accounting and Auditing Standards Board (POB) in the year 2013. In this study, the audit reports of companies traded in Stock Exchange Istanbul in 2013 and 2014 and the audit opinions contained in these reports have been examined. The compliance of the audit reports with the communiques of CMB Auditing Standards and Turkey Auditing Standards has been investigated. It has been examined whether there is a relationship audit opinions and the standard sets applied with between to the sector in which audit firms. In 2013, audit opinions differ from audit companies and do not differ according to the set of standards used in audit. In 2014, audit opinions differ according to audit companies and standard set, and standard set according to audit companies.

Keywords: Independet Audit, Audit Report, Audit Company, Turkey Auditing Standards, Public Oversight, Accounting and Auditing Standards Board, Stock Exchange Istanbul.

Jel Classification: M41, M42, M49.

\footnotetext{
* Öğr. Gör. Bilge Sekizsu, Gaziosmanpaşa Üniversitesi, Almus Meslek Yüksek Okulu, Posta Hizmetleri Programı.

** Fatih Coşkun Ertaş, Atatürk Üniversitesi, İktisadi ve İdari Bilimler Fakültesi, İşletme Bölümü.
} 


\section{GİRiş}

Son y1llarda denetim alanında arka arkaya yaşanan krizler sonucunda toplumun giderek artan güven arayışı denetimde yeni düzenlemeleri zorunlu kılmıştır. Avrupa Birliği Sekizinci Yönergesiyle başlayan, Sarbanes Oxley Kanunu (SOX) ile önem kazanan bu süreçte Uluslararası Denetim Standartları ile tüm dünyada ortak bir denetim dili oluşturulmaya çalışılmış ve bağımsız denetimin etkinliği de önemle vurgulanmaya başlanarak yeni düzenlemeler yapılmaya başlanmıştır. Yapılan düzenlemeler sonucu, işletme yöneticilerinin ve bağımsız denetçilerin sorumlulukları artmıştır. Bu düzenlemelerin en önemli ve somut örneklerinden biri muhasebe ve denetim üzerindeki kontrollerin artmasını sağlayan kamu gözetim kurumlarının oluşturulmasıdır.

$\mathrm{Bu}$ gelişmeler sonucunda, Avrupa Birliği'ne uyum süreci kapsamında, denetimin kalitesini artırmak ve benzer skandalları yaşamamak için dünyadaki örneklerine de bakılarak 2011 yılında 660 sayılı Kanun Hükmünde Kararname (KHK) ile çıkarılan düzenlemede bağımsız muhasebe ve denetim standartlarını belirleme yetkisi KGK'ya verilmiştir. Böylece bağımsız denetim konusundaki dağınık yapı tek bir organda birleştirilmiştir.

KGK'nın yayınladığı bağımsız denetim standartları tebliğlerine göre her bir standart, 01/01/2013 tarihinde ve sonrasında başlayacak hesap dönemlerinden itibaren uygulanmak üzere yayınlandıkları tarihinden itibaren yürürlüğe girmektedir. Bu zamana kadar borsada işlem gören şirketlerin bağımsız denetimlerinde esas alınan SPK'nın yayınladığı denetim standartları yerine artık KGK'nın yayınladığı Türkiye Denetim Standartları esas alınmaya başlanmıştır. Ancak SPK'nın yayınladığı denetim standartları yürürlükten kaldırılmamıştır.

Bu çalışmanın amacı Borsa İstanbul'da işlem gören şirketlerin denetim raporlarında denetçiler tarafından verilen görüşlerin, denetim firmalarıyla, kullanılan denetim standartlarıyla bir alakası olup olmadığını ve bağımsız denetim raporlarının SPK ve TDS tebliğlerine uygunluk derecelerini araştırmaktır. Bu nedenle SPK denetim standartlarından, KGK'nın yayınladığı Türkiye Denetim Standartlarına geçiş yılı olan 2013 ve onu takip eden 2014 yılında Borsa İstanbul'da işlem gören şirketlerin aynı yıllara ait bağımsız denetim raporları incelenmiş ve her iki yılın sonuçları karşılaştırılmıştır.

\section{BAĞIMSIZ DENETÇİ VE DENETIM ŞİRKETLERİ}

TTK'nın 400. Maddesinin birinci fikrasına göre ülkemizde bağımsız denetçiler ve denetim şirketleri KGK tarafindan yetkilendirilir. Denetçiler ruhsat almış Yeminli Mali Müşavir (YMM) ve Serbest Muhasebeci Mali Müşavir (SMMM) unvanını taşıyan kişiler veya bu kişilerin oluşturduğu sermaye şirketleri olabilir. Bağımsız denetim yapabilecek 242 şirket KGK tarafından yetkilendirilmiştir. Bu şirketlerden bir kısmının yabancı denetim firmaları ile lisans anlaşması vardır.

1980'lerde sekiz büyükler (big eight) olarak bilinen en büyük denetim şirketleri, şirket birleşmeleri ve bazılarının isimlerinin finansal skandallara karışması sonucu kapatılmaları sonucu günümüzde dört büyük (big four) denetim firması olarak faaliyetlerine devam etmektedirler. Birçok ülkede faaliyet gösteren çoğu denetim şirketinin dört büyükler olarak anılan PricewaterhouseCoopers, Deloitte Touche Tohmatsu, Ernst\&Young ve KPMG International şirketleri veya diğer yabancı denetim şirketleri ile lisans anlaşmaları vardır. 
Buna göre ülkemizde KGK tarafından yetkilendirilen denetim şirketleri üç grup altında incelenebilir.

\subsection{Dört Büyük Denetim Şirketi}

Türkiye'de faaliyet gösteren ve Dünya'daki dört büyük denetim şirketiyle lisans anlaşması olan, bir bakıma dört büyükleri Türkiye'de temsil eden denetim şirketleri şunlardır:

1- $\quad$ PwC (Başaran Nas Bağımsız Denetim ve YMM A.Ş.),

2- $\quad$ Deloitte Touche Tohmatsu (DRT Bağımsız Denetim ve YMM A.Ş.),

3- $\quad$ Ernst\&Young (Güney Bağımsız Denetim ve YMM A.Ş.),

4- $\quad$ KPMG International (Akis Bağımsız Denetim ve YMM A.Ş.).

\subsection{Yabancı Lisans Anlaşması Olan Diğer Denetim Şirketleri}

Dört büyük denetim şirketinin dışındaki diğer yabancı denetim şirketleri ile lisans anlaşması olan denetim şirketleridir. Bu çalışmada yabancı lisans anlaşması olan denetim şirketlerinin 2013 yılında 40 tanesinin denetim raporları, 2014 yılında ise 34 tanesinin denetim raporları kullanılmıştır.

\subsection{Yabancı Lisans Anlaşması Olmayan Denetim Şirketleri}

Yabancı denetim şirketleri ile lisans anlaşması olmayan denetim şirketleridir. Bu çalışmada yabancı lisans anlaşması olmayan denetim şirketlerinin 2013 yılında 15 tanesinin denetim raporları, 2014 yılında 17 tanesinin denetim raporları kullanılmıştır.

\section{BAĞIMSIZ DENETIM RAPORLARI}

TTK'nın 402. Maddesinin birinci fikrasına göre; denetçi, yapılan denetimin türü, kapsamı, niteliği ve sonuçları hakkında, gereken açıklıkta, anlaşılır, basit bir dille yazılmış ve geçmiş yılla karşılaştırmalı olarak hazırlanmış, finansal tabloları konu alan bir rapor düzenleyecektir.

Finansal tablolara ilişkin denetim raporunun esas bölümünde; (Altaş, 2015:200)

- Defter tutma düzeninin, finansal tabloların ve topluluk finansal tablolarının, kanun ile esas sözleşmenin finansal raporlamaya ilişkin hükümlerine uygun olup olmadığı,

- Yönetim kurulunun denetçi tarafindan denetim kapsamında istenen açıklamaları yapıp yapmadığı ve belgeleri verip vermediği,

- $\quad$ Finansal tablolar ile bunların dayanağı olan defterlerin, öngörülen hesap planına uygun tutulup tutulmadığı,

- $\quad$ Finansal tablolar ile bunların dayanağı olan defterlerin, Türkiye Muhasebe Standartları çerçevesinde, şirketin mal varlığı, finansal ve karlılık durumunun resmini gerçeğe uygun olarak ve dürüst bir şekilde yansıtıp yansıtmadığı açıkça belirtilir.

TTK'nın 403. maddesi denetçi görüşü ile ilgilidir. TTK'nın 403. Maddesinin birinci fikrasına göre; “denetçi, denetimin sonucunu görüş yazısında açıklar. Görüş yazısı, KGK’nin 
belirlediği esaslar çerçevesinde, denetimin konusu, türü, niteliği ve kapsamı yanında denetçinin değerlendirmelerini de içerir”.

Görüş yazısı üç türlü olabilecektir: (Altaş, 2015:206)

1. $\quad$ Olumlu Görüş Yazısı

2. Sinırlı Olumlu Görüş Yazısı

3. Olumsuz Görüş Yazısı

Ancak TTK'da denetçiye belli hallerin varlığında, görüş bildirmekten kaçınma olanağı da getirilmektedir.

Tablo 1'de denetim sonucu elde edilen bulguların önemlilik düzeylerinin ve kullanıcı kararlarına etkilerinin denetçinin vereceği görüşün türünün belirlenmesinde nasıl rol oynadıkları görülmektedir.

Tablo 1. Görüş Oluşturmada Önemlilik

\begin{tabular}{|c|c|c|}
\hline Önemlilik Düzeyi & Kullanıcı Kararlarına Etki & Görüş Türü \\
\hline Tutarlar Önemsizdir & $\begin{array}{c}\text { Kullanıcıların Kararları } \\
\text { Etkilenmez }\end{array}$ & OLUMLU \\
\hline $\begin{array}{l}\text { Tutarlar Önemlidir; Finansal } \\
\text { Tablolar Bir Bütün Olarak Doğru ve } \\
\text { Güvenilirdir }\end{array}$ & $\begin{array}{c}\text { Hata ve Yanlışlıklar } \\
\text { Kullanıcıların Kararlarını } \\
\text { Etkilemektedir, Fakat Finansal } \\
\text { Raporların Dürüst Olmasına } \\
\text { Gölge Düşmemiştir. }\end{array}$ & ŞARTLI \\
\hline $\begin{array}{c}\text { Tutarlar Yeterince Önemlidir; } \\
\text { Finansal Tablolar Bir Bütün Olarak } \\
\text { Doğru ve Güvenilir Değildir. }\end{array}$ & $\begin{array}{c}\text { Finansal tablolara dayalı } \\
\text { olarak karar alan kullanıcıların } \\
\text { tümü, ya da çoğunluğu önemli } \\
\text { derecede etkilenmektedir. }\end{array}$ & $\begin{array}{c}\text { GÖRÜŞ BİLDİRMEKTEN } \\
\text { KAÇINMA } \\
\text { veya } \\
\text { OLUMSUZ GÖRÜŞ }\end{array}$ \\
\hline \multicolumn{2}{|l|}{ Denetçi Bağımsız Değildir. } & $\begin{array}{c}\text { GÖRÜŞ BİLDİRMEKTEN } \\
\text { KAÇINMA }\end{array}$ \\
\hline
\end{tabular}

Kaynak: Ersin Güredin, Denetim ve Güvence Hizmetleri; 14. Baskı, İstanbul: Türkmen Kitabevi, 2014.

TTK'da yer alan denetim raporlarının türleri aynı zamanda KGK'nın yayınladığı TDS'de ve SPK'nın Seri X, 22 numaralı tebliğinde yer almaktadır. Bu standartlarda ve tebliğde denetim raporlarının şekil şartları da yer almaktadır.

Buna göre denetim raporlarında bulunması gereken şekil şartları şunlardır: (BDS700, 21-42 Paragraflar)
a) Başlik
b) Muhatap
c) Giriş Paragrafi
d) Yönetimin Finansal Tablolara İlişkin Sorumluluğu
e) Denetçinin Sorumluluğu
f) Denetçi Görüşü
g) Denetçinin İmzas1
h) Denetçi Raporu Tarihi
i) Denetçinin Adresi 


\subsection{Olumlu Görüş Yazısı}

Olumlu görüş yazısı, mali tabloların denetiminin sonucunda yeterli kanıtın toplanarak mali tabloların aykırılıklardan uzak olduğunun ve şirketin finansal tabloları ile yıllık faaliyet raporunun esas sözleşmedeki finansal raporlamaya, kanuna ve TDS'ye uygun olduğunun denetçi tarafından doğrulanarak açıklanmasıdır.

Dolayısıyla denetçi olumlu görüş verdiğinde görüş yazısında (Altaş, 2015:206)

“Öncelikle 398. Madde ve Türkiye Denetim Standartları uyarınca yapılan denetimde, Türkiye Muhasebe Standartları ve diğer gereklilikler bakımından herhangi bir aykırılığa rastlanmadığını; denetim sırasında elde edilen bilgilerine göre, şirketin veya topluluğun finansal tablolarının doğru olduğunu, mal varlığı ile finansal duruma ve karlılığa ilişkin resmen gerçeğe uygun bulunduğunu ve tabloların bunu dürüst bir şekilde yansıttığını" açıklayacaktır. (TTK, m. 403/ f. 1.)

\subsection{Sınırlı Olumlu (Şartlı) Görüş Yazısı}

Kavramın içerisinde olumlu kelimesinin geçmesinden de anlaşılacağ olumlu görüş yazısı aslında olumlu bir yazıdır. (Altaş, 2015: 208) Bağımsız denetçi tarafından olumlu görüş verilemeyeceği, fakat yönetimle olan herhangi bir anlaşmazlığın veya çalışma alanı sınırlamasının etkisinin olumsuz görüş bildirmeyi veya görüş bildirmekten kaçınmayı gerektirecek kadar önemli ve yaygın olmadığ 1 kanaatine varıldığ 1 durumlarda şartlı görüş verilir. (Selimoğlu vd., 2012:161)

Bu çerçevede TTK'nın 403. Maddesinin üçüncü fikrası denetçiye, “çekinceleri varsa, olumlu görüş yazısını sınırlandırma" olanağı getirilmiştir. Ancak sınırlandırılmış olumlu görüş, "finansal tabloların şirketin yetkili kurullarınca düzeltilebilecek aykırılıklar içerdiği ve bu aykırılıkların tablolarda açıklanmış sonuca etkilerinin kapsamlı ve büyük olmadı̆̆ı", durumlarda verilebilecektir. "Sınır" kelimesiyle anlatılmak istenen denetçinin kendisini sorumluluktan korumak için koyduğu çekinceler değil, sonuçlara ne kadar ve ne ölçüde dayanabileceğidir. Bu itibarla, TTK madde 403 üçüncü fikraya göre; sınırlamanın konusu kapsamı ve düzeltmenin nasıl yapılabileceği, sınırlandırılmış olumlu görüş yazısında açıkça gösterilmelidir. (Altaş, 2015:208)

\subsection{Olumsuz Görüş Yazısı}

Denetçi, işletme yönetiminin bazı finansal tabloları bir bütün olarak işletmenin mali durumunu ve faaliyet sonuçlarını tüm önemli yönleriyle gerçeğe uygun, açık ve dürüst bir biçimde yansıtmadığı kanaatine ulaşırsa olumsuz görüş yazısı verebilir. (Karacan ve Uygun, 2012:247)

Bu çerçevede TTK madde 403 üçüncü fikraya göre denetçinin şirketin yılsonu finansal tabloları ile yıllık raporunun Türkiye Muhasebe Standartları ile Kanuna ve/ veya esas sözleşmenin finansal raporlama hükümlerine uygun olmadığı durumlarda olumsuz görüş yazısı verebilir. 


\subsection{Görüş Bildirmekten Kaçınan Görüş Yazısı}

Denetimin kapsamının görüş bildirilmeyecek kadar önemli bir oranda sınırlandırılmış olması dolayısıyla denetçinin yeterli sayıda ve uygun denetim kanıtı toplayamadı̆̆ durumlarda görüş bildirmekten kaçınılır. (Karacan ve Uygun, 2012:247)

Bu görüş türü nadiren de olsa denetçinin, işletmenin taşıdığı belirsizliklerin, finansal tabloları önemli derecede etkilemesi kanısına varması durumlarında da kullanılabilir. (Buz, 2015:82)

Görüş bildirmekten kaçınma TTK çerçevesinde 403. maddenin 4. fikrasında;

"Şirket defterlerinde, denetlemenin uygun bir şekilde yapılmasına ve sonuçlara varılmasını sağlamaya imkân vermeyecek belirsizliklerin bulunması veya şirket tarafindan denetlenecek hususlarda önemli kısıtlamaların yapılması durumunda denetçi, bunları ispatlayabilecek delillere sahip olmasa bile, gerekçelerini açıklayarak görüş vermekten kaçınabilir. Kaçınma olumsuz görüşün sonuçlarını doğurur. KGK, kaçınmanın sebep ve usulü ile buna dair gerekçenin esaslarını bir tebliğ ile düzenler.” şeklinde yer almaktadır.

\subsection{Dikkat Çekilen Hususlar Paragrafı Eklenen Olumlu Görüş Yazısı}

Daha önce bahsedildiği üzere denetim raporlarında olumlu görüş, şartlı görüş, görüş bildirmekten kaçınma ve olumsuz görüş olmak üzere dört ayrı görüş yazısı yazılabilir. Ancak denetçi çeşitli nedenlerle olumlu denetim raporundan sapabilir. Finansal tablo kullanıcılarının dikkatine sunulması gerekli görülmekle birlikte bağımsız denetim görüşünü etkilemeyen durumların varlığı halinde olumlu denetim görüşü verilir ancak görüşü etkilememekle birlikte bu hususlar denetim raporunda görüş paragrafindan hemen sonra dikkat çekilen hususlar paragrafında ayrıca belirtilir. (Uyar ve Çelik, 2009: 143)

Bu durum TTK'nın 403. maddenin 2. fikrasında;

"Görüş yazısında, yönetim kurulunun finansal tablolara ilişkin konular bakımından sorumluluğunu gerektirecek bir sebebin mevcut olmadığına, varsa bu sorumluluğa dikkat çekilir. Görüş KGK'nin belirlediği şekilde ve herkesin anlayabileceği bir dille yazılır." şeklinde yer almaktadır.

Türkiye Denetim Standartlarında ise BDS 706 "Bağımsız Denetçi Raporunda Yer Alan Dikkat Çekilen Hususlar Ve Diğer Hususlar Paragrafları” 6. Paragrafina göre;

"Denetçi, muhakemesine göre, kullanıcıların finansal tabloları anlamaları açısından temel teşkil edecek derecede öneme sahip olan, finansal tablolarda sunulan veya açıklanan bir hususa kullanıcıların dikkatinin çekilmesinin gerekli olduğunu düşünürse; finansal tabloların önemli yanlışlık içermediği konusunda yeterli ve uygun denetim kanıtı elde edilmiş olması şartıyla, denetçi raporuna Dikkat Çekilen Hususlar paragrafı ekler”. şeklinde yer almaktadır.

BDS 706 "Bağımsız Denetçi Raporunda Yer Alan Dikkat Çekilen Hususlar Ve Diğer Hususlar Paragrafları” A1. Paragrafina göre;

- "İstisnai bir davanın veya düzenleyici bir kurumun yaptığı incelemenin/verdiği kararın gelecekte ortaya çıkacak sonucuna ilişkin bir belirsizliğin bulunmasi. 
- Finansal tablolar üzerinde yaygın etkisi bulunan yeni bir muhasebe standardının (örneğin, yeni bir Türkiye Muhasebe Standardının) yürürlük tarihinden önce (izin verilmesi hâlinde) erken uygulanması.

- $\quad$ İşletmenin finansal durumunu önemli ölçüde etkilemiş veya etkilemeye devam eden ciddi bir afet durumu"

denetçinin Dikkat Çekilen Hususlar Paragrafinın eklenmesinin gerekli olduğunu düşünebileceği durumlara örnek olarak verilebilir.

Dikkat çekilen hususlar paragraflarına ilişkin diğer hükümler;

- $\quad$ SPK'nın Seri X, 22 numaralı tebliğinde 30/31/a paragraflarında,

- $\quad$ BDS 210, "Bağımsız Denetim Sözleşmesinin Şartları Üzerinde Anlaşmaya Varılması", 19(b) paragrafinda, paragraflarında

BDS 560, "Bilanço Tarihinden Sonraki Olaylar", 12(b) ve 16 nc1

- $\quad$ BDS 570, "İşletmenin Sürekliliğì", 19 uncu paragrafında

- $\quad$ BDS 800, “Özel Hususlar - Özel Amaçlı Çerçevelere Göre Hazırlanan Finansal Tabloların Bağımsız Denetimi”, 14 üncü paragrafında yer alır.

Çalışma sırasında incelenen denetim raporlarında bu görüş türünün miktar olarak fazla olduğu görüldüğünden "dikkat çekilen hususlar paragrafi eklenen olumlu görüş" beşinci görüşs şekli olarak çalışmada yer almıştır.

\section{ARAŞTIRMANIN KAPSAMI}

Borsa İstanbul'da 2013 y1lında işlem gören şirket sayısı 424, 2014 yılında 451' dir. Araştırmaya bu şirketlerden bankalar, sigorta şirketleri, finansal kiralama şirketleri ve faktoring şirketleri kapsam dışı bırakılarak 2013 yılında 393, 2014 yılında 417 şirket dâhil edilmiştir. Bu şirketlerden tamamının denetim raporlarına ulaşılmak istense de 2013 yılı için ancak 380 şirketin denetim raporlarına ulaşılmış yani 393 raporun \%96.7 si incelenmiştir. 2014 yılı içerisinde SPK'nın “Ortaklıktan Çıkarma ve Satma Hakları Tebliği” nin yürürlüğe girmesiyle bazı şirketlerin borsa kotundan çıkmasıyla bu yıl için incelenecek bağımsız denetim raporu sayısı da azalmıştır. Geriye kalan şirketlerden ise 2013 yılıyla yapılacak karşılaştırmanın daha sağlıklı olması açısından 2014 yılı için de 380 adet şirketin denetim raporları değerlendirmeye alınmıştır.

\section{VERILERİ TOPLAMA YÖNTEMI}

Araştırmada veriler, 2013 ve 2014 yıllarında borsada işlem gören 380 adet şirketin Kamuyu Aydınlatma Platformu'nun internet sitesinde yayınlanan bağımsız denetim raporlarının incelenmesi sonucu elde edilmiştir. Raporlardan elde edilen veriler, denetimi yapan bağımsız denetim firması, bağımsız denetim sonucu verilen görüş, kullanılan denetim standardı seti, bağımsız denetim raporunda bulunması gereken şekil şartlarının varlığına aittir.

\section{ARASTIRMANIN HİPOTEZLERİ}

Çalışmanın amaçları doğrultusunda test edilmek üzere oluşturulan araştırma hipotezleri aşağıdaki gibidir:

1) $\mathrm{H}_{0}$ : Denetim görüşleri denetim şirketlerine göre farklılaşmamaktadır. 
2) $\mathrm{H}_{0}$ : Denetim görüşleri denetimde kullanılan denetim standart setine göre farklılaşmamaktadır.

3) $\mathrm{H}_{0}$ : Denetimde kullanılan denetim standardı seti denetim şirketlerine göre farklılaşmamaktadır.

\section{VERILERINN ANALIZ YÖNTEMI}

Denetim raporlarının incelenmesi sonucunda elde edilen veriler 1şığında oluşturulan hipotezlerin analizinde SPSS 21.0 İstatistik Paket Programından yararlanılmıştır. İlk olarak denetim raporlarının şekil şartlarına uygunlukları incelenmiş ve raporlarda denetimi yapan şirket, denetim görüşü türü ve kullanılan standart setinin frekans dağılımları yapılmıştır. İkinci olarak verilerimiz kategorik olduğundan araştırmanın hipotezlerine non- parametrik testlerden Kruskal Wallis ve Parametrik Olmayan Çoklu Karşılaştırma Testi uygulanmıştır.

\subsection{Verilerin Frekans Dağılımı}

Araştırma kapsamına giren 2013 ve 2014 y1llarında borsada işlem gören 380 adet şirketin her iki yıla ait denetim raporlarının denetim şirketleri, denetim görüşleri, denetimde kullanılan standart seti ve denetim raporlarında bulunması gereken şekil şartları açısından frekans dağılımları verilmiştir.

Tablo 2. Denetim Raporlarının Şekil Şartlarına Uygunlukları

\begin{tabular}{|l|c|c|c|c|}
\hline \multirow{2}{*}{ Denetim Raporlarında Şekil Şartları } & \multicolumn{2}{|c|}{$\mathbf{2 0 1 3}$} & \multicolumn{2}{|c|}{$\mathbf{2 0 1 4}$} \\
\cline { 2 - 5 } & Adet & Yüzde & Adet & Yüzde \\
\hline Başlık & 376 & 98.95 & 380 & 100 \\
\hline Muhatap & 380 & 100 & 380 & 100 \\
\hline Giriş Paragrafı & 380 & 100 & 380 & 100 \\
\hline İşletme Yönetiminin Sorumluluğu & 380 & 100 & 380 & 100 \\
\hline Bağımsız Denetçinin Sorumluluğu & 380 & 100 & 380 & 100 \\
\hline Bağımsız Denetçi Görüşü & 380 & 100 & 380 & 100 \\
\hline Bağımsız Denetçinin İmzası & 380 & 100 & 380 & 100 \\
\hline Bağımsız Denetim Raporunun Tarihi & 380 & 100 & 380 & 100 \\
\hline Bağımsız Denetim Şirketinin Adresi & 380 & 100 & 380 & 100 \\
\hline
\end{tabular}

Çalışmada standart setlerine uygunlukları bakımından denetim raporlarında bulunması gereken şekil şartlarının varlığı araştırılmıştır. Araştırma sonucunda elde edilen bulguların yer aldığ 1 Tablo 2.'ye göre; 2013 yılında 4 denetim raporuna başlık konulmamıştır, bunların dışında tüm raporlarda şekil şartlarına tamamen uyulduğu görülmektedir. 4 denetim raporunda diğer tüm şekil şartlarına uyulup başlık konulmaması ilginçtir. 2014 yılında ise tüm raporlarda şekil şartlarına tamamen uyulduğu görülmektedir. 
Tablo 3. 2013 Y11ı Denetim Şirketlerinin Denetim Görüşlerine Göre Frekans Dağılımı

\begin{tabular}{|c|c|c|c|c|c|c|c|c|c|c|c|c|}
\hline \multirow{3}{*}{$\begin{array}{l}\text { Denetim } \\
\text { Şirketleri }\end{array}$} & \multicolumn{10}{|c|}{ Denetim Raporu Görüşleri } & & \\
\hline & \multicolumn{2}{|c|}{$\begin{array}{l}\text { Olumlu } \\
\text { Görüşs }\end{array}$} & \multicolumn{2}{|c|}{$\begin{array}{l}\text { Şartlı } \\
\text { Görüşs }\end{array}$} & \multicolumn{2}{|c|}{\begin{tabular}{c|} 
Dikkat \\
Çekilen Husus \\
Paragrafı \\
Eklenen \\
Olumlu Görüşs
\end{tabular}} & \multicolumn{2}{|c|}{$\begin{array}{c}\text { Görüss } \\
\text { Bildirmekten } \\
\text { Kaçınma }\end{array}$} & \multicolumn{2}{|c|}{$\begin{array}{l}\text { Olumsuz } \\
\text { Görüşs }\end{array}$} & \multicolumn{2}{|c|}{ Toplam } \\
\hline & Ad. & $\%$ & $\mathrm{Ad}$. & $\%$ & Ad. & $\%$ & Ad. & $\%$ & Ad. & $\%$ & Ad. & $\%$ \\
\hline $\begin{array}{l}\text { Dört Büyük } \\
\text { Denetim Şirketi }\end{array}$ & 152 & 55.7 & 17 & 34.7 & 24 & 44.4 & 0 & 0 & 0 & 0 & 193 & 50.8 \\
\hline $\begin{array}{l}\text { Diğer Yabanc1 } \\
\text { lisans } \\
\text { anlaşması olan } \\
\text { denetim } \\
\text { şirketleri }\end{array}$ & 105 & 38.5 & 29 & 59.2 & 29 & 53.7 & 3 & 100 & 1 & 100 & 167 & 43.9 \\
\hline $\begin{array}{l}\text { Yabanc1 Lisans } \\
\text { Anlaşması } \\
\text { Olmayan } \\
\text { Denetim } \\
\text { Şirketleri }\end{array}$ & 16 & 5.9 & 3 & 6.1 & 1 & 1.9 & 0 & 0 & 0 & 0 & 20 & 5.3 \\
\hline Toplam & 273 & 71.8 & 49 & 12.9 & 54 & 14.2 & 3 & 0.8 & 1 & 0.3 & 380 & 100 \\
\hline
\end{tabular}

Tablo 3.'e göre halka açık şirketlerin 2013 yılına ait incelenen 380 denetim raporunun 193 tanesi dört büyük denetim şirketi (\% 50,8), 167 tanesi yabancı lisans anlaşması olan denetim şirketleri $(\% 43,9), 20$ tanesi yabancı lisans anlaşması olmayan denetim şirketleri $(\% 5,3)$ tarafından hazırlanmıştır. Buna göre denetim faaliyetlerinin yarısından fazlasını dört büyük denetim şirketi, ona çok yakın bir oranla ikinci sırayı yabancı lisans anlaşması olan denetim şirketleri gerçekleştirmiştir. Yabancı lisans anlaşması olmayan denetim şirketleri ise bağımsız denetimde \% 5 gibi bir oranla çok düşük bir paya sahiptir.

Tabloya göre; 2013 y1lında denetim raporlarının \%71,8'inde (273 tane) olumlu görüş, \%14,2'sinde (54 tane) dikkat çekilen husus paragrafı eklenen olumlu görüş, \% 12,9'unda (49 tane) şartlı görüş, \%0,8'inde (3 adet) görüş bildirmekten kaçınılmış ve \%0,3'ünde (1 tane) olumsuz görüş verilmiştir.

Görüş bildirmekten kaçınılan denetim raporları; Egeplast Plastik Ticaret ve Sanayi A.Ş., Feniş Alüminyum Sanayi ve Ticaret A.Ş. ve Mazhar Zorlu Holding A.Ş.'ye aittir. Olumsuz görüş verilen denetim raporu; Şeker Piliç ve Yem Sanayi Ticaret A.Ş.'ye aittir.

Olumlu denetim görüşlerinin \%55,7'si dört büyük denetim şirketi, \%38,5'i diğer yabancı lisans anlaşması olan denetim şirketleri, \%5.9'u yabancı lisans anlaşması olmayan denetim şirketleri tarafından verilmiştir. Dikkat çekilen husus paragrafı eklenen olumlu denetim görüşlerinin \%44,4'ü dört büyük denetim şirketi tarafından, $\% 53,7$ 'si, diğer yabanc1 lisans anlaşması olan denetim şirketleri tarafından, \%1,9'u yabancı lisans anlaşması olmayan denetim şirketleri tarafından verilmiştir. Şartlı denetim görüşlerinin \%34,7'si dört büyük denetim şirketi tarafından, \%59,2'si diğer yabancı lisans anlaşması olan denetim şirketleri tarafından, \%6,1'i yabancı lisans anlaşması olmayan denetim şirketleri tarafından verilmiştir. Görüş bildirmekten kaçınan denetim raporlarının tamamı diğer yabancı lisans anlaşması olan 
denetim şirketleri tarafından verilmiştir. Sadece 1 tane olan olumsuz görüş yine diğer yabancı lisanslı bir denetim şirketi tarafından verilmiştir.

Tablo 4. 2014 Yılı Denetim Şirketlerinin Denetim Görüşlerine Göre Frekans Dağılımı

\begin{tabular}{|c|c|c|c|c|c|c|c|c|c|c|c|c|}
\hline \multirow{3}{*}{$\begin{array}{l}\text { Denetim } \\
\text { Şirketleri }\end{array}$} & \multicolumn{10}{|c|}{ Denetim Raporu Görüşleri } & & \\
\hline & \multicolumn{2}{|c|}{$\begin{array}{l}\text { Olumlu } \\
\text { Görüş }\end{array}$} & \multicolumn{2}{|c|}{$\begin{array}{l}\text { Şartlı } \\
\text { Görüş̧ }\end{array}$} & \multicolumn{2}{|c|}{$\begin{array}{c}\text { Dikkat } \\
\text { Çekilen Husus } \\
\text { Parag. } \\
\text { Eklenen } \\
\text { Olumlu Görüş }\end{array}$} & \multicolumn{2}{|c|}{$\begin{array}{c}\text { Olumsuz } \\
\text { Görüşş }\end{array}$} & \multicolumn{2}{|c|}{$\begin{array}{c}\text { Görüsş } \\
\text { Bildir. } \\
\text { Kaçınma }\end{array}$} & \multicolumn{2}{|c|}{ Toplam } \\
\hline & Ad. & $\%$ & Ad. & $\%$ & Ad. & $\%$ & Ad. & $\%$ & Ad. & $\%$ & Ad. & $\%$ \\
\hline $\begin{array}{l}\text { Dört Büyük } \\
\text { Denetim Şirketi }\end{array}$ & 150 & 52,4 & 16 & 34 & 14 & 36,8 & 0 & 0 & 0 & 0 & 180 & 47,4 \\
\hline $\begin{array}{l}\text { Diğer Yabanc1 } \\
\text { lisans } \\
\text { anlaşması olan } \\
\text { denetim } \\
\text { şirketleri }\end{array}$ & 108 & 37,8 & 27 & 57,4 & 18 & 47,4 & 0 & 0 & 5 & 62,5 & 158 & 41,6 \\
\hline $\begin{array}{l}\text { Yabanc1 lisans } \\
\text { anlaşması } \\
\text { olmayan } \\
\text { denetim } \\
\text { şirketleri }\end{array}$ & 28 & 9,8 & 4 & 8,5 & 6 & 15,8 & 1 & 100 & 3 & 37,5 & 42 & 11,1 \\
\hline Toplam & 286 & 75,3 & 47 & 12,4 & 38 & 10 & 1 & 0,3 & 8 & 2,1 & 380 & 100 \\
\hline
\end{tabular}

Tablo 4.'e göre halka açık şirketlerin 2014 yılına ait incelenen 380 denetim raporunun 180 tanesi dört büyük denetim şirketi $(\% 47,4), 158$ tanesi yabancı lisans anlaşması olan denetim şirketleri $(\% 41,6), 42$ tanesi yabanc1 lisans anlaşması olmayan denetim şirketi $(\% 11,1)$ tarafindan hazırlanmıştır. Buna göre 2014 yılında da 2013 yılına göre yaptıkları bağımsız denetim sayısında çok küçük bir azalmayla, dört büyük denetim şirketi en büyük paya sahipken, çok az bir farkla yabancı lisans anlaşması olan denetim şirketleri onu takip etmektedir. Yine 2013 yılına göre yabancı lisans anlaşması olmayan denetim şirketleri bağımsız denetimdeki payını iki kat artırmıştır. Bu durum; amacı ekonomiyi dışa bağımlı olmaktan korumak olan ekonomik milliyetçilik anlayışının bir sonucu olabilir. Buna rağmen her iki yıl için de bu sonuçlar bize Türkiye'de yapılan denetim faaliyetlerinin hemen hemen tamamına yakınının yabancı lisans anlaşması olan denetim şirketleri tarafından gerçekleştirildiğini göstermektedir. Bunun sebebi hizmet kalitesinin ve deneyimin yabancı lisans anlaşmalı denetim şirketlerinde daha iyi olduğu düşüncesi olabilir.

Tabloya göre; 2014 yılında denetim raporlarının \%75,3'ünde (286 tane) olumlu görüş, \%10'unda (38 tane) dikkat çekilen husus paragrafı eklenen olumlu görüş, \% 12,4'ünde (47 tane) şartlı görüş, $\% 2,1$ 'inde ( 8 adet) görüş bildirmekten kaçınılmış ve $\% 0,3$ 'ünde (1 tane) olumsuz görüş verilmiştir. 2013 yılına göre görüş bildirmekten kaçınılan denetim raporlarındaki artış (\%0,8'den \%2,1'e yükselmiştir) dikkat çekmekle birlikte, bu sonuçlara göre her iki yıl için de bağımsız denetimlerinde olumlu görüş verilen şirketlerin çoğunluğu oluşturması, borsada işlem gören şirketlerin muhasebe standartlarına uygun kayıt tuttuklarını 
göstermektedir. Diğer denetim görüşlerinin oranlarına bakıldığında uygun bir dağılım gösterdiği söylenebilir.

Görüş bildirmekten kaçınılan denetim raporları; Ar Tarım Organik Gıda A.Ş., CLK Holding A.Ş., Egeplast Ege Plastik Ticaret ve Sanayi A.Ş., Feniş Alüminyum Sanayi ve Ticaret A.Ş., İdaş İstanbul Döşeme Sanayi A.Ş., Latek Lojistik Ticaret A.Ş., Mango Gıda Sanayi Ve Ticaret A.Ş., Mazhar Zorlu Holding A.Ş.'ye aittir. Egeplast Plastik Ticaret ve Sanayi A.Ş., Feniş Alüminyum Sanayi ve Ticaret A.Ş. ve Mazhar Zorlu Holding A.Ş.'nin 2013 yılına ait denetim raporlarında da görüş bildirmekten kaçınılmıştır.

Olumsuz görüş verilen denetim raporu ise, Hitit Holding A.Ş.'ye aittir.

Olumlu denetim görüşlerinin \%52,4'si dört büyük denetim şirketi, \%37,8'i diğer yabancı lisans anlaşması olan denetim şirketleri, \%9.8'u yabancı lisans anlaşması olmayan denetim şirketleri tarafından verilmiştir. Dikkat çekilen husus paragrafı eklenen olumlu denetim görüşlerinin \%36,8'i dört büyük denetim şirketi tarafından, $\% 47,4$ 'ü, diğer yabancı lisans anlaşması olan denetim şirketleri tarafından, \%15,8'i yabancı lisans anlaşması olmayan denetim şirketleri tarafından verilmiştir. Şartlı denetim görüşlerinin \%34'ü dört büyük denetim şirketi tarafından, \%57,4'ü diğer yabancı lisans anlaşması olan denetim şirketleri tarafından, \%8,5'i yabancı lisans anlaşması olmayan denetim şirketleri tarafından verilmiştir. Görüş bildirmekten kaçınılan denetim raporlarının \%62,5'i diğer yabancı lisans anlaşması olan denetim şirketleri tarafından, \%37,5'i yabancı lisans anlaşması olmayan denetim şirketleri tarafından verilmiştir. Sadece 1 tane olan olumsuz görüş yine yabancı lisans anlaşması olmayan bir denetim şirketi tarafından verilmiştir. 2013 yılına göre dikkat çeken değişiklikler diğer yabancı lisans anlaşmalı denetim şirketlerinin görüş bildirmekten kaçınılan denetim raporu sayısındaki artış ve sayı olarak iki katına çıkan yabancı lisans anlaşması olmayan denetim şirketlerinin verdiği tüm görüş türlerindeki artıştır.

Tablo 5. 2013 Y11ı Denetimde Kullanılan Standart Setinin Denetim Şirketlerine Göre Dağılımı

\begin{tabular}{|l|c|c|c|c|c|c|c|c|}
\hline & \multicolumn{6}{|c|}{ Denetim Şirketleri } & \multicolumn{2}{|c|}{} \\
\cline { 2 - 9 } Standart Seti & \multicolumn{2}{|c|}{$\begin{array}{l}\text { Dört Büyük } \\
\text { Denetim Şirketi }\end{array}$} & \multicolumn{2}{|l|}{$\begin{array}{l}\text { Diğer Yabancı lisans } \\
\text { anlaşması olan } \\
\text { denetim şirketleri }\end{array}$} & $\begin{array}{l}\text { Yabancı lisans } \\
\text { anlaşması } \\
\text { olmayan denetim } \\
\text { şirketleri }\end{array}$ & \multicolumn{2}{|c|}{ Toplam } \\
\cline { 2 - 10 }$n$ & Adet & $\%$ & Adet & $\%$ & Adet & $\%$ & Adet & $\%$ \\
\hline $\begin{array}{l}\text { SPK Denetim } \\
\text { Standartları }\end{array}$ & 190 & 98.4 & 144 & 86.2 & 17 & 85 & 351 & 92.4 \\
\hline $\begin{array}{l}\text { Türkiye Denetim } \\
\text { Standartları }\end{array}$ & 3 & 1.6 & 21 & 12.6 & 3 & 15 & 27 & 7.1 \\
\hline $\begin{array}{l}\text { TDS ve SPK } \\
\text { Denetim } \\
\text { Standartlar1 }\end{array}$ & 0 & 0 & 2 & 1.2 & 0 & 0 & 22 & 5.8 \\
\hline Toplam & 193 & 5.8 & 167 & 43.9 & 20 & 5.3 & 380 & 100 \\
\hline
\end{tabular}


Tabloya bakıldığında denetim raporlarının \%92,4'üne SPK'nın UDS ile uyumlu Seri X, No: 22 "Sermaye Piyasasında Bağımsız Denetim Standartları Hakkında Tebliğ" i ile yayınlanan ve 2007 yılından itibaren uygulanmaya başlanan SPK Denetim Standartları uygulanmıştır. Denetim raporlarının \%7,1'sine yine UDS'ye uyumlu olarak KGK'nın yayınladığı ve 2013 yılından itibaren yürürlüğe giren TDS'nin uygulandığını görüyoruz. TDS'nın uygulandığı rapor sayısı oldukça azdır ve sadece 2 denetim raporunda ise SPK Denetim Standartları ve TDS'na uygun olarak denetimin yapıldığı belirtilmiştir. Bu durumun geçiş döneminde gayet normal olduğunu ve ilerleyen yıllarda SPK Denetim Standartları'nın da yürürlükten kaldırılmasıyla denetim raporlarının TDS'ye uygun olarak düzenleneceğini söyleyebiliriz. Zaten her iki standart seti de UDS'nin Türkçe'ye çevrilmesiyle oluşturulduğundan denetim raporları şekil şartları açısından değişmeyecektir.

Dört büyük denetim şirketinin yaptığı 193 denetimin raporlarının \%98,4’ü (190) SPK Denetim Standartları'na, sadece \%1,6'sı (3) TDS'ye uygun olarak hazırlanmıştır. TDS'nı en çok uygulayan diğer yabancı lisans anlaşması olan denetim şirketlerinin yaptığı denetimlerin \%12,6'sında (21) TDS uygulanmıştır. Yabancı lisans anlaşması olmayan denetim şirketleri yaptıkları denetimin \%15'ine (3) TDS'nı uygulamıştır. Diğer yabancı lisans anlaşması olan denetim şirketlerine göre dört büyük denetim şirketinin TDS'yi uygulama oranı oldukça azdır. Ayrıca diğer yabancı lisans anlaşması olan denetim şirketlerinin yaptıkları denetimin \%1,2'sinde (2) hem SPK Denetim Standartları'nı Hem de TDS'yi uyguladıklarını belirtmeleri tek bir standart setini uygulamanın daha uygun olacağından ilginçtir. Bu durum geçiş döneminde SPK Denetim Standartları'nın hala yürürlükte bulunması ve bundan dolayı denetim şirketlerinin nasıl davranacaklarını tam olarak bilememelerinden kaynaklanmış olabilir. Ayrıca her iki standart seti de UDS'na uygun olduğundan, hatta her ikisi de UDS'nın Türkçe'ye çevrilmiş hali olduğundan TDS'na geçişin oldukça az olması dikkat çekicidir.

Tablo 6. 2014 Yılı Denetimde Kullanılan Standart Setinin Denetim Şirketlerine Göre Dağılımı

\begin{tabular}{|c|c|c|c|c|c|c|c|c|}
\hline \multirow{3}{*}{ Standart Seti } & \multicolumn{6}{|c|}{ Denetim Şirketleri } & \multirow{2}{*}{\multicolumn{2}{|c|}{ Toplam }} \\
\hline & \multicolumn{2}{|c|}{$\begin{array}{l}\text { Dört Büyük } \\
\text { Denetim Şirketi }\end{array}$} & \multicolumn{2}{|c|}{$\begin{array}{l}\text { Diğer Yabancı } \\
\text { lisans anlaşması } \\
\text { olan denetim } \\
\text { şirketleri } \\
\end{array}$} & \multicolumn{2}{|c|}{\begin{tabular}{|l|} 
Yabancı lisans \\
anlaşması \\
olmayan denetim \\
şirketleri \\
\end{tabular}} & & \\
\hline & Adet & $\%$ & Adet & $\%$ & Adet & $\%$ & Adet & $\%$ \\
\hline $\begin{array}{l}\text { SPK Denetim } \\
\text { Standartlar1 }\end{array}$ & 1 & 0,6 & 37 & 23,4 & 10 & 23,8 & 48 & 12,6 \\
\hline $\begin{array}{l}\text { Türkiye Denetim } \\
\text { Standartları }\end{array}$ & 1 & 0,6 & 43 & 27,2 & 14 & 33,3 & 58 & 15,3 \\
\hline $\begin{array}{l}\text { TDS ve SPK } \\
\text { Denetim } \\
\text { Standartları }\end{array}$ & 178 & 98,9 & 78 & 49,4 & 18 & 42,9 & 274 & 72,1 \\
\hline Toplam & 180 & 47,4 & 158 & 41,6 & 42 & 11,1 & 380 & 100 \\
\hline
\end{tabular}


Tabloya bakıldığında 2014 yılında denetim raporlarının \%12,6'sına SPK Denetim Standartları, \%15,3'üne TDS, \% 72,1'ine her iki standart setinin de uygulandığını görüyoruz. Denetim raporlarında kullanılan standart setinde 2013 yılına göre çok büyük farklılıklar olduğu söylenebilir. 2014 yılında, TDS'nin yürürlüğe girdiği geçiş yılı olan 2013 yılından sonra sadece SPK Denetim Standartlarının uygulandığı denetim raporu oranında bir azalma olması (\%92,4'den \%12,6ya düşmüştür) beklenen ve olması gereken bir durumdur. Buna karşın TDS'nın uygulandığı rapor oranının oldukça artması beklenirken sadece \% 7,1 'lerden \%15,3'lere yükselebilmiştir. Denetim şirketlerinin 2013 yılındaki denetim raporlarının $\% 0,5$ 'inde uyguladıkları her iki standart setini 2014 yılında denetim raporlarının \% 72,1'inde uygulamalarından dolayı sadece TDS'nin uygulandığı denetim raporu oranında beklenen artışın olmadığı görülüyor. Bu durumun, SPK denetim standartlarının 2014 yılında hala yürürlükten kaldırılmamış olmasından dolayı denetim şirketlerinin raporlarında her iki standart setini uygulamalarından kaynaklandığı söylenebilir. Her iki standart setinin de UDS'ye uyumlu olmasından dolayı, denetim raporlarında iki standart setinin uygulanması bir soruna sebep olmamıştır. Ancak denetim raporlarında sadece TDS uygulanabilmesine rağmen denetim şirketlerinin neden her iki standart setini de uyguladığı araştırılmalıdır.

2014 yılında dört büyük denetim şirketinin yaptığı 180 adet denetimin raporlarının \%0,6's1 (1) SPK Denetim Standartları'na, \%0,6's1 (1) TDS'na, \%98,9'u (178) her iki standart setine uygun olarak hazırlanmıştır. Yabancı lisans anlaşması olan denetim şirketlerinin yaptığ denetimlerin \%23,4'üne (37) SPK Denetim Standartları, \%27,2'sine (43) TDS, \%49,4'üne (78) her iki standart seti uygulanmıştır. Yabancı lisans anlaşması olmayan denetim şirketleri yaptıkları denetimin \%23,8'ine (10) SPK Denetim Standartlarını, \%33,3'üne (14) TDS'nı, $\% 42,9$ 'una her iki standart seti uygulamıştır. Denetim şirketleri denetim raporlarında en az SPK Denetim Standartlarını, en fazla her iki denetim standardını uygulamışlardır. Dört büyük denetim şirketinin TDS'nı sadece 1 denetim raporunda, tamamına yakınında ise her iki denetim standardını uygulaması dikkat çekicidir.

Tablo 7. 2013 Yılı Denetim Görüşlerinin Standart Setine Göre Dağılımı

\begin{tabular}{|c|c|c|c|c|c|c|c|c|}
\hline \multirow{3}{*}{ Denetim Görüşleri } & \multicolumn{6}{|c|}{ Standart Seti } & & \\
\hline & \multicolumn{2}{|c|}{$\begin{array}{l}\text { SPK Denetim } \\
\text { Standartları }\end{array}$} & \multicolumn{2}{|c|}{$\begin{array}{l}\text { Türkiye } \\
\text { Denetim } \\
\text { Standartları }\end{array}$} & \multicolumn{2}{|c|}{$\begin{array}{l}\text { TDS ve SPK } \\
\text { Denetim } \\
\text { Standartları }\end{array}$} & \multicolumn{2}{|c|}{ Toplam } \\
\hline & Adet & $\%$ & Adet & $\%$ & Adet & $\%$ & Adet & $\%$ \\
\hline Olumlu Görüş & 251 & 91.9 & 20 & 7.3 & 2 & 0.7 & 273 & 71.8 \\
\hline Şartlı Görüş & 42 & 85.7 & 7 & 14.3 & 0 & 0 & 49 & 12.9 \\
\hline $\begin{array}{l}\text { Dikkat Çekilen Husus } \\
\text { Paragrafi Eklenen Olumlu } \\
\text { Görüş }\end{array}$ & 54 & 100 & 0 & 0 & 0 & 0 & 54 & 14.2 \\
\hline $\begin{array}{l}\text { Görüş Bildirmekten } \\
\text { Kaçınma }\end{array}$ & 3 & 100 & 0 & 0 & 0 & 0 & 3 & 0.8 \\
\hline Olumsuz Görüş & 1 & 100 & 0 & 0 & 0 & 0 & 1 & 0.3 \\
\hline Toplam & 351 & 92.4 & 27 & 7.1 & 2 & 0.5 & 380 & 100 \\
\hline
\end{tabular}


Tabloya bakıldığında sadece şekil şartları açısından ele alınan denetim raporlarının \%92,4'ü SPK Denetim Standartları'na, \% 7,1'i TDS'na uygun olarak hazırlanmıştır. Olumlu görüş verilen denetim raporlarının \%91,9' u, şartlı görüş verilen denetim raporlarının $\% 85,7$ 'si, dikkat çekilen husus paragrafi eklenen olumlu görüş, verilen, görüş bildirmekten kaçınılan ve olumsuz görüş verilen denetim raporlarının tamamı SPK Denetim Standartlarına uygun olarak düzenlenmiştir. Buna karşın olumlu görüş verilen denetim raporlarının \%7,3’ü ve şartlı görüş verilen denetim raporlarının \%14,3'ü TDS'ye uygunken, dikkat çekilen husus paragrafı eklenen olumlu görüss verilen denetim raporları, görüş bildirmekten kaçınılan denetim raporları ve olumsuz görüş verilen denetim raporları TDS'ye uygun olarak düzenlenmemiştir. Geçiş sürecinde denetim raporlarının büyük kısmı SPK Denetim Standartlarına uygun olmasının olağan bir durum olduğunu söyleyebiliriz.

Tablo 8. 2014 Y1lı Denetim Görüşlerinin Standart Setine Göre Dağılımı

\begin{tabular}{|c|c|c|c|c|c|c|c|c|}
\hline \multirow{3}{*}{ Denetim Görüşleri } & \multicolumn{6}{|c|}{ Standart Seti } & & \\
\hline & \multicolumn{2}{|c|}{$\begin{array}{l}\text { SPK Denetim } \\
\text { Standartları }\end{array}$} & \multicolumn{2}{|c|}{$\begin{array}{l}\text { Türkiye } \\
\text { Denetim } \\
\text { Standartları }\end{array}$} & \multicolumn{2}{|c|}{\begin{tabular}{|l|} 
TDS ve SPK \\
Denetim \\
Standartları \\
\end{tabular}} & \multicolumn{2}{|c|}{ Toplam } \\
\hline & Adet & $\%$ & Adet & $\%$ & Adet & $\%$ & Adet & $\%$ \\
\hline Olumlu Görüş & 32 & 66,7 & 36 & 62,1 & 218 & 79,6 & 286 & 75,3 \\
\hline Şartlı Görüş & 9 & 18,8 & 12 & 20,7 & 26 & 9,5 & 47 & 12,4 \\
\hline $\begin{array}{l}\text { Dikkat Çekilen Husus } \\
\text { Paragrafi Eklenen Olumlu } \\
\text { Görüş }\end{array}$ & 5 & 10,4 & 6 & 10,3 & 27 & 9,9 & 38 & 10 \\
\hline Olumsuz Görüş & 0 & 0 & 0 & 0 & 1 & 0,4 & 1 & 0,3 \\
\hline $\begin{array}{l}\text { Görüş Bildirmekten } \\
\text { Kaçınma }\end{array}$ & 2 & 4,2 & 4 & 6,9 & 2 & 0,7 & 8 & 2,1 \\
\hline Toplam & 48 & 12,6 & 58 & 15,3 & 274 & 72,1 & 380 & 100 \\
\hline
\end{tabular}

Tabloya bakıldığında sadece şekil şartları açısından ele alınan denetim raporlarının \%12,6'sı SPK Denetim Standartları'na, \% 15,3'ü TDS'na,\%72,1'i her iki denetim standardına uygun olarak hazırlanmıştır. Olumlu görüş verilen denetim raporlarının \%66,7'si, şartlı görüş verilen denetim raporlarının \%18,8'i, dikkat çekilen husus paragrafı eklenen olumlu görüş verilen denetim raporlarının\%10,4'ü, görüş bildirmekten kaçınılan denetim raporlarının \%4,2'si SPK Denetim Standartlarına uygun olarak düzenlenmiştir. Buna karşın olumlu görüş verilen denetim raporlarının \%62,1'i ve şartlı görüş verilen denetim raporlarının \%20,7'si, dikkat çekilen husus paragrafı eklenen olumlu görüş verilen denetim raporlarının \% 10,3 'ü TDS'ye uygunken, olumsuz görüş verilen denetim raporları TDS'ye uygun olarak düzenlenmemiştir. Olumlu görüş verilen denetim raporlarının \%79,6's1, şartlı görüş verilen denetim raporlarının $\% 9,5$ 'i, dikkat çekilen husus paragrafı eklenen olumlu görüş verilen denetim raporlarının $\% 9,9$ 'u, her iki denetim standardına uygun olarak düzenlenmiştir. 


\subsection{Araştırma Hipotezlerinin Analizi}

Araştırma hipotezlerinin test edilmesinde Kruskal-Wallis testi (K-W) kullanılmıştır. Kruskal-Wallis testi normal dağılım göstermeyen $\mathrm{k}$ sayıda (3 veya daha fazla) grubun ortalamaları arasındaki farklılığın anlamlılığını test etmek amacıyla kullanılan (http://mustafaotrar.net/istatistik/kruskal-wallis-h-testi/, 2016) tek yönlü varyans analizinin parametrik olmayan alternatifidir. (Özdamar, 2013:443) Ancak bu test tekniği hangi grubun hangi gruptan farklı olduğuyla ilgili bir bilgi vermediğinden hipotezlere ayrıca parametrik olmayan Çoklu Karşılaştırma Testi uygulanmıştır.

Kruskal-Wallis testi sonuçlarına göre anlamlılık düzeyi $\% 5$ eşit veya $\% 5$ 'in altında olan hipotezler reddedilmiş, anlamlılık düzeyi \%5'in üzerindeki hipotezler kabul edilmiştir.

Test için hipotezler şu şekilde oluşturulur:

$\mathrm{H}_{0}$ : Ana kütleler arasında anlamlı fark yoktur.

$\mathrm{H}_{1}$ : Ana kütleler arasında anlamlı fark vardır.

Oluşturulan hipotezlerin analizinden elde edilen sonuçlara aşağıda yer verilmiştir.

\section{1- Denetim Görüş̧lerinin Denetim Firmalarına Göre Farklılaşması}

Dört büyük denetim şirketi, yabancı lisanslı denetim şirketleri ve yabancı lisans anlaşması olmayan denetim şirketlerinin verdikleri denetim görüşlerinin arasında anlamlı bir farklılığın olup olmadığını araştırmak amacıyla $\mathrm{H}_{0}$ : "Denetim Görüşleri Denetim Firmalarına Göre Farklılaşmamaktadır" şeklinde oluşturulan birinci hipotezin analizine ilişkin Kruskall Wallis test sonuçları aşağıdaki tablolarda gösterilmiştir.

Tablo 9. Denetim Görüşleri -Denetim Şirketleri İlişkisi (2013)

\begin{tabular}{|l|c|c|c|c|}
\hline \multicolumn{1}{|c|}{$\mathbf{H}_{\mathbf{0}}$ Hipotezi } & $\begin{array}{c}\text { Test } \\
\text { İstatistiği }\end{array}$ & $\begin{array}{c}\text { Serbestlik } \\
\text { Derecesi }\end{array}$ & Anlamıılık & Karar \\
\hline $\begin{array}{l}\text { Denetim Görüşleri } \\
\begin{array}{l}\text { Denetim } \\
\text { Şirketlerine Göre } \\
\text { Farklılaşmamaktadır. }\end{array}\end{array}$ & 11,709 & 2 & $\mathbf{0 0 3}$ & $\begin{array}{c}\mathrm{H}_{0} \text { Hipotezi } \\
\text { Reddedilir. }\end{array}$ \\
\hline
\end{tabular}

Kruskal Wallis test sonuçlarına göre \% 5 anlamlılık seviyesinde Anlamlılık $=0,003<$ 0,05 olduğundan, H0 Hipotezi reddedilir. Yani H1: "Denetim görüşleri denetim şirketlerine göre farklılaşmaktadır" Hipotezi kabul edilir. Bu farklılığın hangi denetim şirketleri arasında olduğu Kruskal Wallis Testi ile hesaplanamadı̆̆ından parametrik olmayan Çoklu karşılaştırma testi yapılmıştır. Bu testin sonuçları Tablo 10.’da gösterilmiştir. 
Tablo 10. Denetim Görüşleri -Denetim Şirketleri Çoklu Karşılaştırma Testi (2013)

\begin{tabular}{|c|c|c|c|c|}
\hline Grup1- Grup2 & $\begin{array}{l}\text { Test } \\
\text { İstatistiği }\end{array}$ & $\begin{array}{l}\text { Standart } \\
\text { Hata }\end{array}$ & $\begin{array}{l}\text { Standart } \\
\text { Test } \\
\text { İstatistiği }\end{array}$ & Anlamlılık \\
\hline $\begin{array}{lcc}\text { Yabanc1 lisans anlaşması } & \text { olmayan } \\
\text { denetim şirketleri- } & \text { Dört } & \text { Büyük } \\
\text { Denetim Şirketi } & & \\
\end{array}$ & 5,831 & 20,385 & ,286 & 1,000 \\
\hline 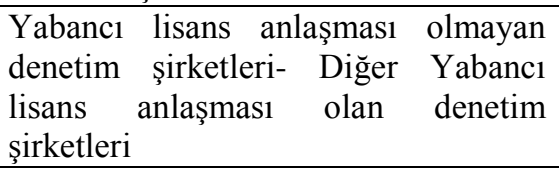 & 35,869 & 20,534 & 1,747 & ,242 \\
\hline $\begin{array}{l}\text { Dört Büyük Denetim Şirketi- Diğer } \\
\text { Yabanc1 lisans ans aşması olan } \\
\text { denetim şirketleri }\end{array}$ & $-30,037$ & 9,171 & $-3,275$ & ,003 \\
\hline
\end{tabular}

Çoklu Karşılaştırma Test sonuçlarına göre Dört Büyük Denetim Şirketi ile Diğer Yabancı lisans anlaşması olan denetim şirketleri arasında önemli denetim görüşü farklılıkları vardır (Anlamlılık=0,003<0,05). Yabancı lisans anlaşması olmayan denetim şirketleri ile Dört Büyük Denetim Şirketi arasında denetim görüssleri açısından fark yoktur (Anlamlılık=1,000>0,05).Yabancı lisans anlaşması olmayan denetim şirketleri ile Diğer Yabancı lisans anlaşması olan denetim şirketleri arasında da denetim görüşleri açısından fark yoktur.

Tablo 11. Denetim Görüşleri -Denetim Şirketleri İlişkisi (2014)

\begin{tabular}{|l|c|c|c|c|}
\hline \multicolumn{1}{|c|}{$\mathbf{H}_{\mathbf{0}}$ Hipotezi } & $\begin{array}{c}\text { Test } \\
\text { İstatistiği }\end{array}$ & Serbestlik Derecesi & Anlamlılık & Karar \\
\hline $\begin{array}{l}\text { Denetim Görüşleri } \\
\begin{array}{l}\text { Denetim } \\
\text { Şirketlerine Göre } \\
\text { Farklılaşmamaktadır. }\end{array}\end{array}$ & 13,144 & 2 & $\mathbf{0 , 0 0 1}$ & $\begin{array}{c}\mathrm{H}_{0} \text { Hipotezi } \\
\text { Reddedilir. }\end{array}$ \\
\hline
\end{tabular}

Kruskal Wallis test sonuçlarına göre \% 5 anlamlılık seviyesinde Anlamlılık $=0,001<$ 0,05 olduğundan, H0 Hipotezi reddedilir. Yani H1: "Denetim görüşleri denetim şirketlerine göre farklılaşmaktadır” Hipotezi kabul edilir. Bu farklılığın hangi denetim şirketleri arasında olduğu Kruskal Wallis Testi ile hesaplanamadığından parametrik olmayan Çoklu karşılaştırma testi yapılmıştır. Bu testin sonuçları Tablo 12.'de gösterilmiştir.

Tablo 12. Denetim Görüşleri -Denetim Şirketleri Çoklu Karşılaştırma Testi (2014)

\begin{tabular}{|l|l|l|l|c|}
\hline Grup1- Grup2 & $\begin{array}{l}\text { Test } \\
\text { İstatistiği }\end{array}$ & $\begin{array}{l}\text { Standart } \\
\text { Hata }\end{array}$ & $\begin{array}{l}\text { Standart } \\
\text { Test } \\
\text { İstatistiği }\end{array}$ & Anlamlılık \\
\hline $\begin{array}{l}\text { Dört Büyük Denetim Şirketi -Yabanc1 } \\
\text { lisans anlaşması olan denetim } \\
\text { şirketleri }\end{array}$ & $-29,998$ & 9,047 & $-3,316$ & $\mathbf{0 , 0 0 3}$ \\
\hline $\begin{array}{l}\text { Dört Büyük Denetim Şirketi -Yabanc1 } \\
\text { lisans anlaşması olmayan denetim } \\
\text { şirketleri }\end{array}$ & 33,925 & 14,220 & $-2,386$ & 0,051 \\
\hline $\begin{array}{l}\text { Diğer Yabancı lisans anlaşması olan } \\
\text { denetim şirketleri- Yabancı lisans } \\
\text { anlaşmasılmayan denetim şirketleri }\end{array}$ & $-3,927$ & 14,406 & $-0,273$ & 1,000 \\
\hline
\end{tabular}


Çoklu Karşılaştırma Test sonuçlarına göre Dört Büyük Denetim Şirketi ile Diğer Yabancı lisans anlaşması olan denetim şirketleri arasında önemli denetim görüşü farklılıkları vardır (Anlamlılık=0,003<0,05). Dört Büyük Denetim Şirketi ile Yabancı lisans anlaşması olmayan denetim şirketleri arasında denetim görüşleri açısından fark yoktur (Anlamlılık=0,051>0,05). Yabancı lisans anlaşması olan denetim şirketleri ile Yabancı lisans anlaşması olmayan denetim şirketleri arasında da denetim görüşleri açısından fark yoktur (Anlamlil1k=0,051>0,05).

\section{2- Denetim Görüşlerinin Denetimde Kullanılan Denetim Standart Setine Göre Farklılaşması}

Bağımsız denetim sırasında SPK Denetim Standartları veya TDS'nın uygulanmasının verilen denetim görüşlerinin arasında anlamlı bir farklılığa sebep olup olmadığını araştırmak amacıyla $\mathrm{H}_{0}$ : "Denetim Görüşleri Denetimde Kullanılan Standart Setine Göre Farklılaşmamaktadır" şeklinde oluşturulan ikinci hipotezin Kruskal Wallis Testi sonuçları aşağıdaki tablolarda verilmiştir.

Tablo 13. Denetim Görüşleri- Standart Seti İlişkisi (2013)

\begin{tabular}{|l|c|c|c|c|}
\hline \multicolumn{1}{|c|}{$\mathbf{H}_{\mathbf{0}}$ Hipotezi } & $\begin{array}{c}\text { Test } \\
\text { İstatistiği }\end{array}$ & Serbestlik Derecesi & Anlamılık & Karar \\
\hline $\begin{array}{l}\text { Denetim Görüşleri } \\
\begin{array}{l}\text { Denetimde } \\
\text { Kullanılan Standart Setine } \\
\text { Göre Farklılaşmamaktadır. }\end{array}\end{array}$ & 1,324 & 2 &, 516 & $\begin{array}{c}\mathrm{H}_{0} \text { Hipotezi Kabul } \\
\text { Edilir. }\end{array}$ \\
\hline
\end{tabular}

Kruskal Wallis test sonuçlarına göre $\% \quad 5$ anlamlılık seviyesinde Anlamlılık=0,516 $>0,05$ olduğundan, H0 Hipotezi kabul edilir. Yani Denetim görüşleri denetimde kullanılan standart setine göre farklılaşmamaktadır. Her iki standart setinin UDS'nin Türkçe'ye çevrilmiş hali olması, hangi standart seti uygulanırsa uygulansın aynı denetim görüşü verilecektir. Dolayısıyla elde edilen test sonuçları durumun olumlu olduğunu göstermektedir.

Tablo 14. Denetim Görüşleri- Standart Seti İlişkisi (2014)

\begin{tabular}{|l|c|c|c|c|}
\hline \multicolumn{1}{|c|}{$\mathbf{H}_{\mathbf{0}}$ Hipotezi } & $\begin{array}{c}\text { Test } \\
\text { İstatistiği }\end{array}$ & $\begin{array}{c}\text { Serbestlik } \\
\text { Derecesi }\end{array}$ & Anlamlılık & Karar \\
\hline $\begin{array}{l}\text { Denetim Görüşleri } \\
\begin{array}{l}\text { Denetimde } \\
\text { Kullanılan Standart Setine } \\
\text { Göre Farklılaşmamaktadır. }\end{array}\end{array}$ & 12,201 & 2 & $\mathbf{0 , 0 0 2}$ & $\begin{array}{c}\mathrm{H}_{0} \text { Hipotezi } \\
\text { Reddedilir. }\end{array}$ \\
\hline
\end{tabular}

Kruskal Wallis test sonuçlarına göre $\% \quad 5$ anlamlılık seviyesinde Anlamlılık=0,002<0,05 olduğundan, H0 Hipotezi reddedilir. Yani Denetim görüşleri denetimde kullanılan standart setine göre farklılaşmaktadır. Bu farklılığın hangi standart setleri arasında olduğunu tespit etmek amacıyla yapılan çoklu karşılaştırma testinin sonuçları Tablo 15'de yer almaktadır. Her iki standart setinin UDS'nin Türkçe'ye çevrilmiş hali olması nedeniyle verilen denetim görüşlerinin kullanılan standart setine göre farklılaşması ilginçtir. 
Tablo 15. Denetim Görüşleri - Standart Setleri Çoklu Karşılaştırma Testi (2014)

\begin{tabular}{|l|c|c|c|c|}
\hline Grup1- Grup2 & $\begin{array}{c}\text { Test } \\
\text { İstatistiği }\end{array}$ & $\begin{array}{c}\text { Standart } \\
\text { Hata }\end{array}$ & $\begin{array}{c}\text { Standart } \\
\text { Test } \\
\text { İstatistiği }\end{array}$ & Anlamlılık \\
\hline SPK Denetim Standartlar1- TDS & 10,211 & 116,192 & $-0,631$ & 1,000 \\
\hline $\begin{array}{l}\text { SPK Denetim Standartlar1- Her iki } \\
\text { standart seti }\end{array}$ & 27,024 & 12,985 & 2,081 & 0,112 \\
\hline TDS- Her iki standart seti & 37,235 & 11,994 & 3,104 & $\mathbf{0 , 0 0 6}$ \\
\hline
\end{tabular}

Çoklu karşılaştırma test sonuçlarına göre; TDS ve Her iki denetim standardı seti uygulandıkları denetim raporlarında verilen denetim görüşleri bakımından farklılık göstermektedir (Anlamlılık=0,006<0,05). Diğer standart setleri arasında denetim görüşleri bakımından herhangi bir farklı1ık bulunmamaktadır.

\section{3- Denetim Standardı Setinin Denetim Şirketlerine Göre Farklılaşması}

Dört Büyük Denetim Şirketi, Yabancı Lisanslı Denetim Şirketleri ve Yabancı lisans anlaşması olmayan denetim şirketlerinin denetimlerinde uyguladıkları denetim standard1 setleri arasında fark olup olmadığını araştırmak amacıyla $\mathrm{H}_{0:}$ "Denetimde kullanılan denetim standardı seti denetim firmalarına göre farklılaşmamaktadır" şeklinde oluşturulan üçüncü hipotezin Kruskal Wallis Test sonuçları aşağıdaki tablolarda verilmiştir.

Tablo 16. Denetim Standart Seti- Denetim Şirketleri İlişkisi (2013)

\begin{tabular}{|l|c|c|c|c|}
\hline \multicolumn{1}{|c|}{$\mathbf{H}_{\mathbf{0}}$ Hipotezi } & $\begin{array}{c}\text { Test } \\
\text { İstatistiği }\end{array}$ & $\begin{array}{c}\text { Serbestlik } \\
\text { Derecesi }\end{array}$ & Anlamıılık & Karar \\
\hline $\begin{array}{l}\text { Denetimde kullanılan } \\
\text { denetim standardı seti } \\
\text { denetim firmalarına göre } \\
\text { farklılaşmamaktadır. }\end{array}$ & 20,573 & 2 & $\mathbf{, 0 0 0}$ & $\begin{array}{c}\mathrm{H}_{0} \text { Hipotezi } \\
\text { reddedilir. }\end{array}$ \\
\hline
\end{tabular}

Kruskal Wallis test sonuçlarına göre $\% \quad 5$ anlamlılık seviyesinde Anlamlılık=0,000<0,05 olduğundan, H0 Hipotezi reddedilir. Yani H1: "Denetimde kullanılan denetim standardı seti denetim firmalarına göre farklılaşmaktadır" hipotezi kabul edilir. $\mathrm{Bu}$ farklılığın hangi denetim şirketleri arasında olduğu Kruskal Wallis Testi ile hesaplanamadığından parametrik olmayan Çoklu karşılaştırma testi yapılmıştır. Bu testin sonuçları Tablo 17.'de gösterilmiştir.

Tablo 17. Denetim Standart Seti- Denetim Şirketleri Çoklu Karşılaştırma Testi (2013)

\begin{tabular}{|l|c|c|c|c|}
\hline \multicolumn{1}{|c|}{ Grup1- Grup2 } & Test İstatistiği & $\begin{array}{c}\text { Standart } \\
\text { Hata }\end{array}$ & $\begin{array}{c}\text { Standart Test } \\
\text { İstatistiği }\end{array}$ & Anlamlılık \\
\hline $\begin{array}{l}\text { Dört Büyük Denetim Şirketi- } \\
\text { Diğer Yabancı lisans anlaşması } \\
\text { olan denetim şirketleri }\end{array}$ & $-23,266$ & 5,339 & $-4,357$ & $\mathbf{, 0 0 0}$ \\
\hline $\begin{array}{l}\text { Dört Büyük Denetim Şirketi- } \\
\text { Yabancı lisans anlaşması olmayan } \\
\text { denetim şirketleri }\end{array}$ & $-25,412$ & 11,868 & $-2,141$ &, 097 \\
\hline $\begin{array}{l}\text { Diğer Yabanc1 lisans anlaşması } \\
\text { olan denetim şirketleri- Yabancı } \\
\text { lisans anlaşması olmayan denetim } \\
\text { şirketleri }\end{array}$ & $-2,146$ & 11,954 &,- 180 & 1,000 \\
\hline
\end{tabular}


Çoklu Karşılaştırma Test sonuçlarına göre Dört Büyük Denetim Şirketi ile Diğer Yabancı lisans anlaşması olan denetim şirketleri arasında uyguladıkları standart seti açısından önemli farklılık vardır (Anlamlılık=0,000<0,05). Dört Büyük Denetim Şirketi ile Yabanc1 lisans anlaşması olmayan denetim şirketleri arasında uyguladıkları standart seti açısından farklılık yoktur (Anlamlılık=0,097>0,05). Diğer Yabancı lisans anlaşması olan denetim şirketleri ile Yabancı lisans anlaşması olmayan denetim şirketleri arasında uyguladıkları standart seti açısından farklılık yoktur (Anlamlılık=1,000>0,05).

Tablo 18. Denetim Standart Seti- Denetim Şirketleri İlişkisi (2014)

\begin{tabular}{|l|c|c|c|c|}
\hline \multicolumn{1}{|c|}{$\mathbf{H}_{\mathbf{0}}$ Hipotezi } & $\begin{array}{c}\text { Test } \\
\text { İstatistiği }\end{array}$ & $\begin{array}{c}\text { Serbestlik } \\
\text { Derecesi }\end{array}$ & Anlamlılık & Karar \\
\hline $\begin{array}{l}\text { Denetimde kullanılan } \\
\text { denetim standardı seti } \\
\text { denetim firmalarına göre } \\
\text { farklılaşmamaktadır. }\end{array}$ & 118,896 & 2 & $\mathbf{0 , 0 0 0}$ & $\begin{array}{c}\mathrm{H}_{0} \text { Hipotezi } \\
\text { reddedilir. }\end{array}$ \\
\hline
\end{tabular}

Kruskal Wallis test sonuçlarına göre $\% \quad 5$ anlamlılık seviyesinde Anlamlılık $=0,000<0,05$ olduğundan, H0 Hipotezi reddedilir. Yani H1: "Denetimde kullanılan denetim standardı seti denetim firmalarına göre farklılaşmaktadır” hipotezi kabul edilir. Hangi denetim şirketleri arasında fark olduğu Tablo 19.'da Çoklu karşılaştırma testi ile tespit edilmiştir.

Tablo 19. Denetim Standart Seti- Denetim Şirketleri Çoklu Karşılaştırma Testi (2014)

\begin{tabular}{|l|c|c|c|c|}
\hline \multicolumn{1}{|c|}{ Grup1- Grup2 } & Test İstatistiği & $\begin{array}{c}\text { Standart } \\
\text { Hata }\end{array}$ & $\begin{array}{c}\text { Standart Test } \\
\text { Istatistiği }\end{array}$ & Anlamlılık \\
\hline $\begin{array}{l}\text { Dört Büyük Denetim Şirketi- } \\
\text { Diğer Yabanc1 lisans anlaşması } \\
\text { olan denetim şirketleri }\end{array}$ & 94,323 & 9,425 & 10,007 & $\mathbf{0 , 0 0 0}$ \\
\hline $\begin{array}{l}\text { Dört Büyük Denetim Şirketi- } \\
\text { Yabanc1 lisans anlaşması olmayan } \\
\text { denetim şirketleri }\end{array}$ & 105,337 & 14,815 & 7,110 & $\mathbf{0 , 0 0 0}$ \\
\hline $\begin{array}{l}\text { Diğer Yabancı lisans anlaşması } \\
\text { olan denetim şirketleri- Yabanc1 } \\
\text { lisans anlaşması olmayan denetim } \\
\text { şirketleri }\end{array}$ & 11,014 & 15,009 & 0,734 & 1,000 \\
\hline
\end{tabular}

Çoklu Karşılaştırma Test sonuçlarına göre Dört Büyük Denetim Şirketi ile Diğer Yabancı lisans anlaşması olan denetim şirketleri arasında (Anlamlılık $=0,000<0,05)$ ve Dört Büyük Denetim Şirketi ile Yabancı lisans anlaşması olmayan denetim şirketleri arasında (Anlamlılık=0,000<0,05) uyguladıkları standart seti açısından önemli farklılık vardır. Diğer Yabancı lisans anlaşması olan denetim şirketleri ile Yabancı lisans anlaşması olmayan denetim şirketleri arasında uyguladıkları standart seti açısından farklılık yoktur (Anlamlıl1k=1,000>0,005). 


\section{SONUÇ}

Bu çalışmada Borsa İstanbul'da işlem gören şirketlerin denetim raporları incelenerek denetim görüşleri ile denetim şirketleri, denetimde kullanılan denetim standardı seti ve denetim standardı seti ile denetim şirketleri arasındaki ilişki araştırılmıştır.

Çalışmada denetimi yapan denetim şirketleri üç grup altında incelenmiştir. Bunlardan dört büyük denetim şirketi ve diğer yabancı lisans anlaşması olan denetim şirketleri denetim faaliyetlerinin 2013 yılında \%94,7 'sini ve 2014 yılında \%88,9'unu gerçekleştirmiştir. Buna göre Türkiye'de yapılan denetim faaliyetlerinin hemen hemen tamamına yakınının yabancı lisans anlaşması olan denetim şirketleri tarafından gerçekleştirildiği söylenebilir. Bunun sebebi hizmet kalitesinin ve tecrübenin yabancı lisans anlaşması olmayan denetim şirketlerine göre daha iyi olduğu düşüncesi olabilir.

2013 y1lında denetim raporlarının \% 92,4 'ü SPK Denetim Standartlarına, \% 7,1'i Türkiye Denetim Standartlarına ve sadece \% 0,5'i her iki standart setine uygunluk göstermektedir. Geçiş sürecinde bu oranlar normal kabul edilebilir ancak içerik olarak her iki standart setinin UDS'ye uygun olduğundan TDS'ye geçiş oranının daha fazla olabileceği tahmin edilirken 2014 yılında denetim raporlarının sadece \%15,3'ü TDS'na uygundur. Raporların \%72,1'inde her iki standart setinin uygulandığ görülmektedir. Bu durum oldukça dikkat çekici ve araştırılması gerekir. Bu durumun SPK Denetim Standartlarının halen yürürlükten kalkmamış olmasından kaynaklandığı söylenebilir. SPK Denetim Standartları hâla yürürlükte olsa bile sadece TDS uygulanabiliyorken denetim şirketlerinin neden her iki standart setini uygulamayı tercih ettikleri araştırılmalıdır.

Her iki yılda da denetim görüşleri denetim şirketlerine göre farklılaşmaktadır. Bu fark dört büyük denetim şirketi ile diğer yabancı lisans anlaşması olan denetim şirketleri arasında çıkmıştır. $\mathrm{Bu}$ farkın sebebinin incelenen denetim raporlarında en çok şartlı görüş, görüş bildirmekten kaçınma ve olumsuz görüşün diğer yabancı lisans anlaşması olan denetim şirketleri tarafından verilmesi olduğunu söyleyebiliriz. Bunun güçlü şirketlerin denetimlerini genelde dört büyük denetim şirketine yaptırmalarından ve bu nedenle dört büyük denetim şirketinin genelde olumlu görüş bildirmesinden kaynaklandığı düşünülmekte, bu durumun başka nedenleri varsa araştırılmalıdır. Şayet farklı bir denetim şirketiyle çalışmak verilen denetim görüşünü farklılaştırıyorsa, geçmiş yıllarda yaşanan denetim skandalları dikkate alınarak, bu durumun bağımsız denetim alanında ciddi bir sorunun varlığından söz edilebilir.

2013 yılında denetim görüşleri denetimde uygulanan denetim standardı setine göre farklılaşmamaktadır. Yani yapılan denetimde TDS da uygulansa, SPK Denetim Standartları da uygulansa denetim görüşü değişmeyecektir. Her iki standart setinin de UDS'nın bir çevirisi olmasından dolayı bu sonucun çıkması gayet doğal ve olumludur.

2014 yılında ise tam tersi bir sonuç çıkmıştır. Denetim görüşleri denetimde uygulanan denetim standardı setine göre farklılaşmaktadır. Bu farklılık TDS ve her iki denetim standardı setinin uygulandıkları denetim raporlarında verilen denetim görüşleri arasında oluşmuştur.

Her iki yılda da denetimde uygulanan denetim standardı seti denetim şirketlerine göre farklılaşmaktadır. Bu fark 2013 yılında dört büyük denetim şirketi ile diğer yabancı lisans anlaşması olan denetim şirketleri arasında çıkmıştır. Bunun nedeni diğer yabancı lisans 
anlaşması olan denetim şirketlerinin geçiş sürecine daha çok ayak uydurarak dört büyük denetim şirketine nazaran denetimlerinde TDS'nı uygulama oranlarının daha fazla olmasıdır. 2014 yılında ise; dört büyük denetim şirketi ile yabancı lisans anlaşması olan denetim şirketi ve dört büyük denetim şirketi ile yabancı lisans anlaşması olmayan denetim şirketleri arasında çıkmıştır. Bu durumun dört büyük denetim şirketinin her iki standart setini uygulama oranlarının yüksekliğinden kaynaklandığı söylenebilir.

Yapılan çalışmanın 1şığında gelecek yılların da bağımsız denetim raporları ele alınarak hangi standart setinin kullanıldığ 1 , kullanılan standart setleri ve denetim şirketlerinin, denetim görüşleri üzerindeki etkileri araştırılıp, geçmiş yılların sonuçlarıyla karşılaştırılarak çalışma genişletilebilir.

\section{KAYNAKLAR}

Altaş, Soner (2015), Şirket Denetimi, 6. Baskı, Seçkin Yayıncılık, Ankara.

Buz, Bülent (2015), Bağımsız Denetim, 1. Baskı, Hilal Yayıncılık ve Seminer A.Ş., İstanbul.

BDS 706 Bağımsız Denetçi Raporunda Yer Alan Dikkat Çekilen Hususlar Ve Diğer Hususlar, 14.03.2014 tarihli ve 28941 sayıl1 Resmi Gazete.

BDS 700 Finansal Tablolara İlişkin Görüş Oluşturma ve Raporlama Standardı, 18.03.2014 tarihli ve 28945 sayılı Resmi Gazete.

Güredin, Ersin (2014), Denetim ve Güvence Hizmetleri, 14. Bask1, Türkmen Kitabevi, İstanbul.

Karacan, Sami - Uygun, Rahmi (2012), Denetim ve Raporlama, Umuttepe Yayınları, Kocaeli.

Özdamar, Kazım (2013), Paket Programlar ile İstatistiksel Veri Analizi, Cilt 1. Nisan Kitabevi, Eskişehir.

Selimoğlu, Seval- Uzay, Şaban- Uyar, Süleyman- Özbirecikli, Mehmet- Poroy Arsoy, AylinBaşar, Banu (2012), Muhasebe Denetimi ve Mali Analiz, 1. Bask1, Anadolu Üniversitesi Yayınları, Eskişehir.

Uyar, Süleyman - Muhsin Çelik (2009), “İstanbul Menkul Kıymetler Borsası'nda İşlem Gören Şirketlerin Denetim Görüşlerinin ve Denetim Raporlarının Denetim Şirketleri Açısından Araştırılması”. Muhasebe ve Finansman Dergisi, Sayı 41, ss. 140- 156.

Sermaye Piyasası Kurulu (12.06.2006), Sermaye Piyasasında Bağımsız Denetim Standartları Hakkında Tebliğ (Seri: X, No: 22), Ankara: T.C. Resmi Gazete (26196 sayılı).

T.C. Yasalar (14.02.2011), 6102 Say1lı Türk Ticaret Kanunu. Ankara: T.C Resmi Gazete (27846 sayili).

http://mustafaotrar.net/istatistik/kruskal-wallis-h-testi/( 20.08.2017) 
